\title{
Epistles of the brethren of purity and their vision of a pluralistic world
}

\section{Introduction}

The authors of a famous encyclopedia of the philosophical and religious sciences assumed the pseudonym Ikhwan al-Safa' (The Brethren of Purity), describing themselves as a group of fellowseekers after truth. Members of a religio-political underground movement, they deliberately concealed their identity so that their epistles, entitled Rasa'il Ikhwan al-Safa' wa-Khullan al-Wafa' (The Epistles of the Brethren of Purity and the Friends of Loyalty), would gain wider circulation and appeal to a broad cross-section of Arab society, both Muslims and non-Muslims. Over the centuries, the authorship of the Epistles has been ascribed to various individuals and groups, such as to Imam Ja far al-Șadiq (d. 148/765), to the great astronomer and mathematician al-Majriti (d. ca. 398/1007), and to the Mu tazila, to the Qaramița of Bașra and to the Șufis. The assertion of Abu Hayyan al-Tawhidi (d. 414/1023) that the treatises were composed by a group of learned men in Bașra during the middle of the fourth/tenth century was widely accepted until recently. Al-Qifț (d. 646/1248), the famous biographer of physicians and philosophers, was the first to express his skepticism about al-Tawhidi's attribution. In 1932, Husayn al-Hamdani stated that the Isma' ili Musta 'li-Ṭayibi tradition attributes the authorship of the said encyclopedia to the hidden imam Ahmad. He also indicated certain marked features of the Epistles that are manifestly Isma'ili in character. Yves Marquet, who authored numerous studies on the Rasa' $\mathrm{il}$, believes that Isma 'ilis composed the Epistles over a long period of time and perhaps the final form was settled upon around the middle of the fourth/tenth century. He further contends that the Rasa' $i l$ represent the oldest extant source for Isma ili doctrines. In 1978, Abbas Hamdani deconstructed alTawhidi's theory and pointed out the untrustworthiness of his report. Additionally, he published the earliest reference to the Rasa'il found in the Isma ili literature. He rejects Qarmati authorship of the Epistles and argues that they were compiled before the establishment of the Fatimid state in North Africa in 297/909 as an ideological and intellectual spearhead in support of Fațimid political activities. In short, the Isma ili character of the Epistles is no longer in dispute.

I fully concur with Hamdani's findings. In my latest study, I reiterated that Abu Hayyan al-Tawhidi's narration does not stand up to close scrutiny and must be abandoned. Similarly I have refuted at length Stern and Madelung's thesis based on al-Tawhidi's account of the authorship and dating of the Rasa' $i l$. All the internal evidence points to the fact that the authors of the Rasa'il were not affiliated with the Qaramita, and certainly their Epistles were composed much earlier than the middle of the fourth/tenth century. There are no traces of any influence from al-Farabi's (d. 339/950) strand of Neoplatonism on their thought. I have, therefore, argued that as far as philosophy is concerned, the Epistles represent a post-Kindi (d. ca. 256/870) component of Neoplatonism. Furthermore, I pointed out that the oldest extant copy of the Rasa'il, from 'Atif Efendi (MS 1681) in Istanbul and transcribed in 578/1182, is almost three centuries later than the first circulation of the encyclopedia. We can, therefore, state that the text of this manuscript, and, in turn, of the entire encyclopedia, is not well attested or documented. Myself and other editors (of the latest critical edition with an annotated English translation, published by the Oxford University Press) have indicated that extant manuscript copies
Volume 3 Issue 2 - 2019

Ismail K Poonawala
Professor Emeritus of Arabic \& Islamic Studies, University of
California, USA

Correspondence: Ismail K. Poonawala, Professor Emeritus of Arabic \& Islamic Studies, University of California, Los Angeles, USA,Email ismailp@gmail.com

Received: February 05, 2019 | Published: March 19, 2019

of the Epistles are marred by copyists' intentional and unintentional interpolations. I think those interpolations occurred soon after the circulation of the Rasa'il, prior to the emergence of proto-archetypes and the subsequent establishment of various manuscript traditions adhering to these archetypes. My above assumption is based on the fact that there is a major lacuna of almost three centuries between the time of the Rasa'il's composition and the transcription of the oldest extant copy as stated above. Unless new evidence comes to light, the present state of our knowledge will not change. Finally, I should add that if we concede that Isma ilis compiled the Rasa' $i l$, the identity of the group that did so cannot be precisely determined. The pre-Fatimid Isma ili movement was a coalition composed of numerous groups with the goal of supplanting the 'Abbasid dynasty with a Shi' $i$ one. Nonetheless, the names of the authors will remain a mystery.

The philosophical system of the Rasa'il is a synthesis of reason and revelation wherein the cosmos is viewed a unified, organic whole. The philosophical structure and the cosmology are derived from Neoplatonism and Neo-Pythagoreanism. Eclectic in nature, the system draws on various faiths and philosophies, with a strong undercurrent of rationalism and humanism. The Brethren of Purity offered a new political program under the aegis of an 'Alid imam, and their utopia, referred to as al-madina al-fadila (the spiritual, virtuous city), or dawlat ahl al-khayr (the government of virtuous people), was to be governed by a law-giving philosopher-prophet. The organization and arrangement of the Epistles and their classification of the sciences reflect this ultimate objective. Without going into further details about the superstructure of the hierarchy of beings originating with the Intellect emanating from One (God), humanity is described as the noblest of all creation. The other three kingdoms: minerals, plants, and animals, are made subservient to it. The unity and complexity of the human being's soul and body make him/her a microcosm. Humans, by virtue of their position in this hierarchy, are the central link in a long chain of beings; below them is the animal kingdom and above them is the world of angels, and they are connected to both. In the Perfect Human Being, who has realized his divine origin, the process of generation in descending order comes to an end and the reverse journey in ascending order starts. The human being, therefore, fulfills the purpose of creation. Given their grandiose view of the cosmic world, they also formulated a model of a pluralistic world held together by values of inclusiveness, tolerance and understanding between different religions and cultures. Yet, their so-called "liberal and inclusive" interpretation of Islam, put forward more than a millennium ago, was still rooted in the spirit of the Qur' an, particularly the themes present in verses 62 of surat al-Baqara and 69 of surat al- 
Ma 'ida, ${ }^{1}$ along with verses 136 and 285 of surat al-Baqara and 84 of surat Al 'Imran. ${ }^{2}$

The Epistles occupy a unique position in the history of Islamic thought and exercised a great influence on the Muslim elite. The existence of a large number of manuscript copies of the text (more than one hundred) scattered throughout the world is an eloquent witness to their popularity and influence. Al-Ghazali (d. 505/1111) understood very well that the threat of the Isma'ilis and the Rasa'il was not merely political but also intellectual. He perceived that it was not simply Mu'tazilite rationalism, for in their synthesis the Isma ilis went far beyond rationalism to encompass the entire spectrum of scientific thought. They integrated the Greek sciences, philosophy, and formal reasoning into one universal valid truth, synonymous with religious reality. Therefore, in addition to his Fada'ih al-Batiniyya (or al-Mustazhiri), which is exclusively devoted to refuting the newly formulated doctrine of ta 'lim by Hasan-e Șabbah (d. 518/1124), that one must accept the absolute authority of the infallible Imam in religious faith, he refuted the Isma 'ilis in several other books. In some of those polemical works he loses his customary academic serenity and becomes almost shrill in his denunciation. Referring to the Rasa' $i l$ in his Munqidh min al-dalal (Deliverance from Error), which has been called Ghazali's "Apologia pro doctrina sua," he states that the Rasa' il Ikhwan al-Safa' is really the refuse of philosophy. Because,

${ }^{1}$ Those who believe and those who are Jews and the Christian and Sabi 'un those who believe in God and the Last Day and act righteously - Their reward is with their Lord. No fear will be upon them nor will they grieve. Qur' an 2:62; 5:69).

${ }^{2}$ We believe in God and in what was revealed to us, and in what was revealed to Abraham, Issac, Ishmael, Jacob and the tribes, and in what was given to Moses and Jesus, and in what was given to the prophets from their Lord. We make no distinction between any of them. Qur' an 2:136. We find more or less the same contents in other two verses. he adds, their doctrines are based on the feeble beliefs of Pythagoras whose assumptions are the weakest of all philosophical principles and had already been refuted by Aristotle.

\section{Select bibliography}

In his article "Ikhwan al-Șafa'," in Encyclopedia of Islam, $2^{\text {nd }}$ edn., Yves Marquet provided an extensive bibliography; Abbas Hamdani, "Abu Hayyan al-Tawhidi and the Brethren of Purity," International Journal of Middle East Studies 9 (1978); 345-53 and "An Early Fațimid Source on the Time and Authorship of the Rasa'il Ikhwan al-Safa'," Arabica 26 (1979), 62-75; Ismail Poonawala, "Ikhwan alSafa'," Encyclopedia of Religion, $2^{\text {nd }}$ edn.; idem, "Why We Need an Arabic Critical Edition with an Annotated English Translation of the Rasa'il Ikhwan al-Safa'," in The Ikhwan al-Safa' and their Rasa'il: An Introduction, ed. Nader El-Bizri, Oxford, 2008, 33-57; idem, "Humanism in Isma'ili Thought: The Case of the Rasa'il Ikhwan al-Safa'," in Universality in Islamic Thought, ed. Michael Morony, London, 2014, 65-144; idem, "Introduction to Epistle 41," in Epistles of the Brethren of Purity: Sciences of the Soul and Intellect, Part II, An Arabic Critical Edition and English Translation of Epistles 39-41, eds. and trans. by Carmela Baffioni and Ismail K. Poonawala, Oxford, 2017, 277-308.

\section{Acknowledgment}

None.

\section{Conflicts of interest}

The author declares that there is no conflict of interest. 